\title{
Assessment of the influence of the effective water-cement ratio on the workability and strength of a commercial concrete used for the construction of concrete caissons
}

\section{Evaluación de la influencia de la relación agua-cemento efectiva en la trabajabilidad y resistencia de un hormigón comercial empleado para la fabricación de cajones portuarios}

\section{Eduardo González-Díaz (Main and Corresponding Author)}

Departamento de Técnicas y Proyectos en Ingeniería y Arquitectura, Escuela Politécnica Superior de Ingeniería, Universidad de La Laguna.

Avda. Ángel Guimerá Jorge. 38204- La Laguna. Tenerife, Islas Canarias (Spain)

egonza@ull.es

\section{Elena Jaizme-Vega}

Servicio de Laboratorios y Calidad de la Construcción. Consejería de Obras Públicas, Transportes y Política Territorial. Gobierno de Canarias.

C/ Talavera, s/n. Llano del Moro. 38291- Santa Cruz de Tenerife, Islas Canarias (Spain)

ejaiveg@gobiernodecanarias.org

\section{Javier Jubera-Pérez}

Servicio de Laboratorios y Calidad de la Construcción. Consejería de Obras Públicas, Transportes y Política Territorial. Gobierno de Canarias

C/ Talavera, s/n. Llano del Moro. 38291- Santa Cruz de Tenerife, Islas Canarias (Spain)

jjubper@gobiernodecanarias.org

\section{Manuscript Code: 907}

Date of Acceptance/Reception: 20.07.2018/16.05.2017

DOI: $10.7764 /$ RDLC.17.2.231

\begin{abstract}
The aim of this research is to assess the influence of the effective water-cement ratio on the concrete workability and strength. This study was carried out with a concrete used for the manufacture of concrete caissons for the construction of a harbour in the south of Tenerife. This commercial concrete was elaborated with basaltic aggregates but with a partial replacement of basalt sand by a sand called "African Sand". As a reference, a concrete containing only basaltic aggregates was manufactured. The water absorption of the aggregates influence the amount of water available for the hydration of the cement. The value of water absorption for the basaltic sand is higher than African sand. This presence of aggregates with different water absorption in the concrete allowed the proposal of a methodology for the determination of the effective water-cement ratio in the fresh concrete. This methodology was used for the calculation of water available for the hydration of the cement in the fresh concrete. The results allowed the answer for two questions regarding the behaviour of these concrete mixes. Firstly, how the incorporation of this African sand influences effective water-cement ratio and the concrete workability. Secondly, how this incorporation influences the strength of the concrete.
\end{abstract}

Key words: Effective water-cement ratio, aggregates, workability, African sand, basaltic sand.

\section{Resumen}

El objetivo de esta investigación es evaluar la influencia de la relación agua-cemento efectiva en la trabajabilidad y resistencia del hormigón. Este estudio fue llevado a cabo con un hormigón empleado en la fabricación de cajones portuarios en la construcción de un Puerto en el sur de Tenerife. Este hormigón comercial fue elaborado con áridos basálticos pero con una sustitución parcial de arena basáltica por una arena llamada "arena africana". Como referencia, se fabricaron hormigones que contenían solamente áridos basálticos. La absorción de agua por parte de los áridos influye en la cantidad de agua disponible para la hidratación del cemento. El valor de la absorción de agua para la arena basáltica es mayor que para la arena Africana. Esta presencia en el hormigón de áridos con distinta absorción de agua permitió proponer una metodología para la determinación de la relación agua-cemento efectiva en el hormigón fresco. Los resultados permitieron dar respuesta a dos cuestiones referentes al comportamiento de estas mezclas de hormigón. La primera, cómo influye la incorporación de la arena Africana en la relación agua-cemento efectiva y en la trabajabilidad del hormigón. La segunda, cómo esa incorporación influye en la resistencia del hormigón. 
The network of pores of the aggregates causes a reduction of effective water content for the cement hydration due to water absorption in the pores of these aggregates. This reduction of the water-cement ratio in fresh concrete is usually regarded as a negative phenomenon as it can lead the loss of the mixture`s workability (Zhang \& Gjørv, 1990). On the other hand, the water absorption by the aggregates in the fresh concrete is also associated with the improvement of the cement paste adhesion that can increase the strength and durability of the concrete (Zhang \& Gjørv, 1992).

This article present an example (regarding a studied case) of how the substitution of a part of the basaltic aggregates with a sand called African sand, which is less porous, influences the workability and strength of the concrete. To study the influence of the effective water-cement ratio on the concrete workability and strength, a methodology is proposed to determine this effective water-cement ratio in the fresh concrete, i.e. water availability in the concrete mix. The application of this methodology needs to use of aggregates with different water absorption values in the concrete mix. In this research, the studied concrete was employed for manufacturing concrete caissons used for the construction a harbour in the south of Tenerife. The incorporation of African sand reduces the total water absorption by the aggregates because the African sand is less porous. This incorporation is usually carried out because, in many cases, it seems to improve the properties of the concrete. However, no references are documented regarding the behaviour of concrete made with these mixtures of basaltic and African sand.

\section{Description of the Problem}

Currently, in Tenerife (Islas Canarias, Spain), the aggregates used for the manufacture of concretes are obtained by the crushing of basaltic rocks. However, it is a common practice to replace a part of the basaltic aggregates with a sand called "African sand", which is mainly composed of silica and calcium carbonate. This substitution reduces the total water absorption by the aggregates because the African sand is less porous.

Due to water absorption of the aggregates, the water availability for the hydration of the cement is less than the total added to the mixtures. However, the current standards limit the water-cement ratio without considering the amount of water absorbed by the aggregates. For example, the Spanish annex for the application of European Standard (UNEEN 206-1, 2008) or Spanish Code on Structural Concrete (EHE-08, 2008) limit the maximum water/cement ratio according to each exposure class, but without making an allowance for the water absorption of the non-lightweight aggregates.

The use of the African sand implies an economic and environmental cost because this sand was imported from the African continent. This cost would be justified if it improves the characteristics of the concrete. This article forms part of a research to explain the influence on the water absorption of the aggregates with respect to the concrete workability and strength.

\section{State of the Art}

No references were found regarding the behaviour of concrete made with basaltic sands or with mixtures of basaltic and African sand. However, in relevant literature, several articles research the influence of the high absorption of lightweight aggregates in the properties of concrete (Henkensiefken, Castro, Bentz, Nantung, \& Weiss, 2009; Golias, Castro, \& Weiss, 2012; Domagała, 2015; Castro, Keiser, Golias, \& Weiss, 2011; Zhang \& Zong, 2014). These researches do not only cover the lightweight aggregates with high water absorption. With respect to non-lightweight aggregates, the researcher (Alhozaimy, 2009) also studies the effect on the strength and the loss of the workability of the concretes which were manufactured with limestone aggregates having a percentage of water absorption between 1.3 and $1.9 \%$. The concrete workability defines its application and use in construction practices. The aggregates occupy between $70-$ $80 \%$ of the volume of the concrete and, therefore it has an important influence on the features of the fresh and hardened concrete (Alhozaimy, 2009).

\section{Material}

The materials used in this research correspond to those used to make commercial concrete caissons for a harbour in the south of Tenerife. The cement used was type II, portland cement with the addition of natural pozzolana (P), sea water resistant with a resistance type 42.5 and being of high initial resistance. Its designation, according to (UNE $80303-$ $2,2011)$, is: II/A-P 42.5R/MR. Also, the same amount of the chemical admixtures used to manufacture the commercial 
concrete were added in all concrete mixes included in this work. Three aggregate types were used: a basaltic coarse aggregate (G10/20), a basaltic sand (A0/6) and an African sand (A0/2). Figure 1 shows an image of the sands.

Figure 1. Image of basaltic sand (left) and African sand (right). The separation between the markings of the ruler is $1 \mathrm{~mm}$. Source: own elaboration.
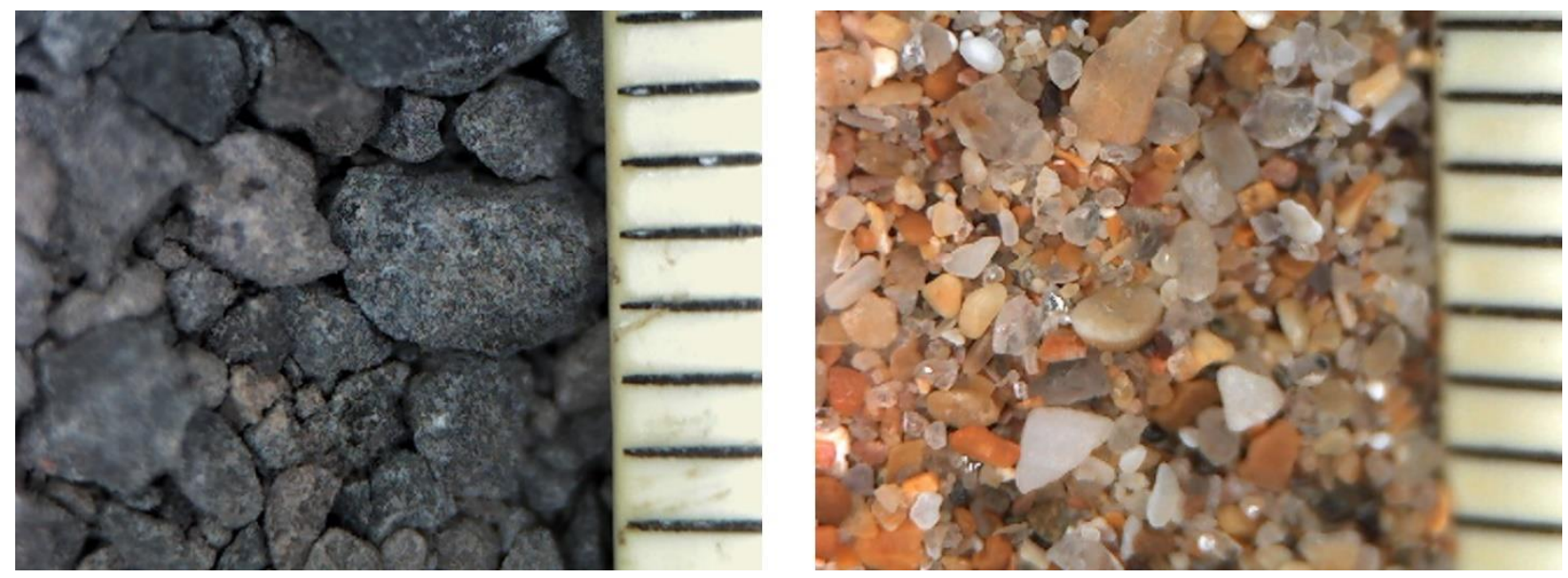

\section{Chemical composition of the aggregates}

The chemical composition of the basaltic and African sand was obtained by combining two techniques of chemical analysis: CHNS elemental analysis with a FlashEA-1112 CHNS Analyser and by an X-ray diffraction incorporated in scanning electron microscopy. The chemical composition of the basaltic aggregate was very similar in the six zones analysed with an Energy Dispersive X-Ray Analysis (EDX) of different grains. The chemical composition of the African sand depends on the colour of the grains (Figure 1). Thus, the grey grains contains mostly $\mathrm{Ca}, \mathrm{O}$, and $\mathrm{C}$, but the grains of other colours also contains $\mathrm{Mg}$, Si, Fe and Al. The African sand is mainly composed of a mixture of silica and calcium carbonate. The presence of silica and calcium carbonate in the powdered African sand were found by using of the X-ray diffraction method using a PANalytical Empyrean X-ray diffractometer.

\begin{tabular}{lccc}
\multirow{2}{*}{ Table 1. Percentage of the chemical elements present in the basaltic aggregates and African sand. Source: own elaborat } \\
\cline { 2 - 4 } & & \multicolumn{2}{c}{ \% Weight } \\
\cline { 2 - 4 } Elements & Basaltic aggregates & African sand \\
\cline { 2 - 4 } $\mathrm{Ca}$ & 7.4 & 49.1 & 34.7 \\
$\mathrm{O}$ & 37.9 & 45.3 & 45.4 \\
$\mathrm{C}$ & $<0.5$ & 4.9 & 4.9 \\
$\mathrm{Si}$ & 25.5 & - & 3.6 \\
$\mathrm{Mg}$ & 1.8 & - & 6.8 \\
$\mathrm{Fe}$ & 8.1 & - & 2.8 \\
$\mathrm{Al}$ & 9.5 & - & 0.8 \\
$\mathrm{Na}$ & 3.8 & - & - \\
$\mathrm{Ti}$ & 2.1 & - & - \\
$\mathrm{K}$ & 2.3 & - & - \\
$\mathrm{P}$ & 0.7 & - & - \\
$\mathrm{Others}$ & $<0.5$ & $<0.5$ & $<0.5$ \\
\hline
\end{tabular}

\section{Density and water absorption of the aggregates}

The density and water absorption values for the aggregates were determined according to the pycnometer method and water absorption (as percentage of dry mass) after immersion for 24 hours, respectively (EN 1097-6, 2014). Table 2 shows the values of density and total water absorption for each aggregate type. The apparent density ( $\left.\rho_{a}\right)$ is equal to the mass of the aggregates divided by its volume including the solid material and closed pores, and the effective density $\left(\rho_{\mathrm{rd}}\right)$ is equal to the mass of the aggregates divided by its volume including the solid material, open and closed pores. 
Other non-lightweight aggregates studied (Alhozaimy, 2009), both fine and coarse, have water absorption in the range of $1-2 \%$ by weight. However, the basaltic aggregates, which are relatively dense, show a water absorption greater than $3 \%$ (Table 2). The basaltic aggregates, obtained by the crushing of basaltic rocks in Tenerife, have a higher water absorption than the African sand ( $0.47 \%$, see Table 2 ) or other type of basaltic aggregates (1.45\%) (Karpuz, Vefa Akpinar, \& Mutlu Aydin, 2017).

Table 2. Average values of density and water absorption. Source: own elaboration.

\begin{tabular}{lcccc}
\multicolumn{5}{c}{ Table 2. Average values of density and water absorption. Source: own elaboration. } \\
\hline Aggregate type & Reference & $\begin{array}{c}\rho_{\mathrm{a}} \\
\left(\mathrm{kg} / \mathrm{m}^{3}\right)\end{array}$ & $\begin{array}{c}\rho_{\mathrm{rd}} \\
\left(\mathrm{kg} / \mathrm{m}^{3}\right)\end{array}$ & $\begin{array}{c}\text { Water absorption } \\
(\%)\end{array}$ \\
\hline Basaltic sand & $\mathrm{A} 0 / 6$ & 2870 & 2700 & 3.41 \\
African sand & $\mathrm{A} 0 / 2$ & 2730 & 2710 & 0.47 \\
Basaltic coarse & $\mathrm{G} 10 / 20$ & 2790 & 2620 & 3.82 \\
\hline
\end{tabular}

\section{Size distribution of the aggregates and fine particles}

The particle size distribution, shown in Figure 2, was determined according to the sieving method (EN 933-1, 2012). The size of fine particles less than $63 \mu \mathrm{m}$ was determined using a Particle Size Analyser from Malvern Instruments based on laser light scattering. For the African and basaltic fines, the diameter of the mean sphere of the same volume (D [4, 3]) was $54.76 \pm 0.12 \mu \mathrm{m}$ and $30.83 \pm 0.43 \mu \mathrm{m}$, respectively. These values show that the fines of the basaltic sand are more than $40 \%$ less in diameter of the average sphere in volume. The parameter of uniformity in the basaltic fines $(0.73 \pm 0.01)$ indicates that these fines are less angular and more rounded than African fines $(0.47 \pm 0.01)$.

The average content of the fine particles in the coarse aggregate G10/20 and African sand A0/2 was $0.7 \%$ and $1 \%$, respectively. In both cases, the standard deviation was less than 0.1 . The amount of fine particles of the A0/6 basaltic sand was $9.2 \%$ with a standard deviation of 0.8 . The amount of fine particles $(<63 \mu \mathrm{m})$ was obtained by sieving.

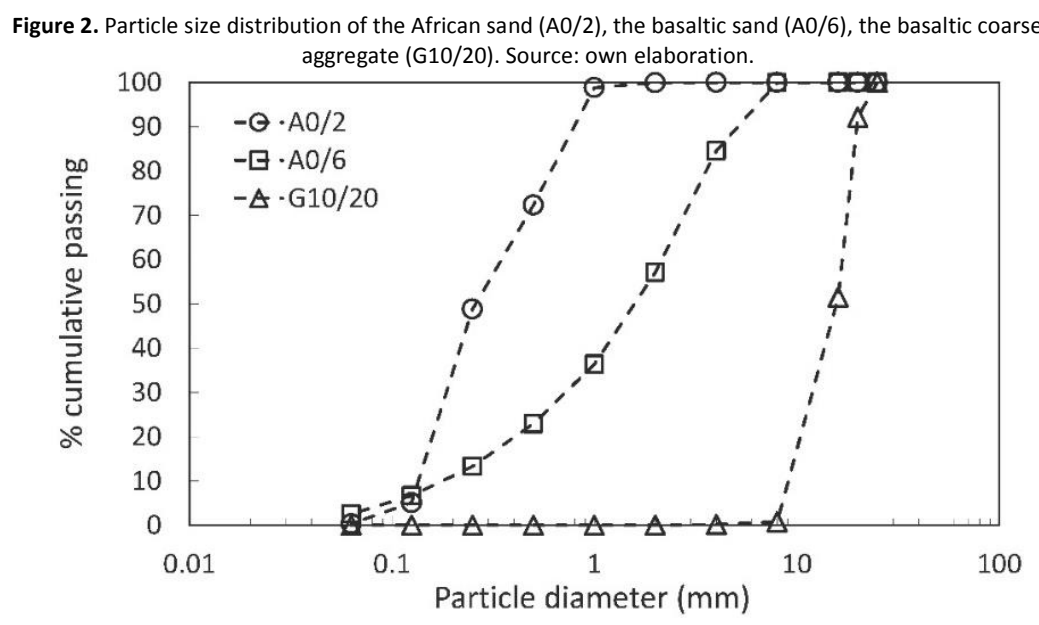

Methodology

\section{Experimental procedure and preparation of the tested concretes}

The dosage of the concrete studied is a commercial dosage used to manufacture of the concrete caissons for a maritime works. This dosage, called AF06 in this article, is the suitable for the requirements of this construction process. The AF06 mix contains a partial replacement of basalt sand with African sand (A0/2) which has a much lower fines content than the basaltic sand. To evaluate only the effect of the incorporation of the African sand to the concrete mixture (AF06), an AB06 mix, containing only basaltic aggregates, was used as a reference. The behaviour of the AF06 mix was compared with the behaviour observed for the AB06 mix. The proportion of total fines in the AB06 concrete mix was adjusted by removing basaltic fines until the same amount of fines as AF06 mix was achieved. Table 3 shows the average values and ranges of the percentage of cement, the total ratio w/c, and the percentage of fines for the AF06 and AB06 concretes. The adjustment of the content of total fine particles in the mixtures AB06 and AF06 was achieved by sieving. 


$\begin{aligned} & \text { Table 3. Average values and standard deviation }(\overline{\boldsymbol{x}} \pm s) \text { of the percentage of cement weight, the } \\
& \text { total ratio w/c, and the percentage of fine particles of the AF06 and AB06 mixes. Source: own } \\
& \text { elaboration. }\end{aligned}$
\begin{tabular}{lcc}
\hline AF06 $(\bar{x} \pm s)$ & AB06 $(\bar{x} \pm s)$ \\
\hline Cement (\%) & $16.9 \pm 0.0$ & $16.8 \pm 0.2$ \\
Total water/cement ratio & $0.48 \pm 0.02$ & $0.48 \pm 0.03$ \\
Fine particles $<63 \mu \mathrm{m}(\%)$ & $5.7 \pm 0.3$ & $6.1 \pm 0.7$ \\
\hline
\end{tabular}

The AB06 mix contains $47.8 \%$ of a basaltic coarse aggregate (G10/20) and $52.2 \%$ of the basaltic sand (A0/6) as the total weight of the aggregates. On the other hand, the AF06 mix also contains $47.8 \%$ of a basaltic coarse aggregate (G10/20) but it contains $35.0 \%$ of the basaltic sand (A0/6) and $17.2 \%$ of an African sand (A0/2). The AF06 mix corresponds exactly to the dosage of the commercial concrete used for the manufacture of harbour caissons. Table 4 shows the dosage of each component for mixtures AF06 and AB06.

Table 4. Dosage of each of the components of the AF06 and AB06 mixes per cubic meter of concrete.

\begin{tabular}{|c|c|c|}
\hline & AF06 & AB06 \\
\hline Cement & 401 kg & $401 \mathrm{~kg}$ \\
\hline Water & $193 \mathrm{dm}^{3}$ & $193 \mathrm{dm}^{3}$ \\
\hline G10/20 (Basaltic coarse aggregate) & 835 kg & $835 \mathrm{~kg}$ \\
\hline A0/6 (Basaltic sand) & $611 \mathrm{~kg}$ & $912 \mathrm{~kg}$ \\
\hline A0/2 (African sand) & $300 \mathrm{~kg}$ & - \\
\hline Plasticizer/retarding admixture ${ }^{(1)}$ & $1.8 \%$ & $1.8 \%$ \\
\hline Superplasticizer admixture ${ }^{(1)}$ & $1.5 \%$ & $1.5 \%$ \\
\hline
\end{tabular}

All the mixes of concrete included in this research were prepared in the Laboratory Service and Quality of Construction of the Government of the Canary Islands. The manufactured specimens totalled 80 specimens in 20 mixtures, i.e. 40 specimens in 10 mixtures for each dosage: AF06 and AB06.

The properties of the concrete are influenced mainly by the characteristics and percentage of the cement added, the water-cement ratio, the characteristics of the aggregates and chemical admixtures used. The average cement dosage in all mixtures was $401 \pm 10 \mathrm{~kg} / \mathrm{m}^{3}$. This value is higher than the minimum cement content required for the environment IIIb (EHE-08, 2008), called XS2 in reference (UNE-EN 206-1, 2008). The amount of water added in each mixture was the same. Before the preparation of each mixture, an aggregate sample was taken to determine the moisture of the aggregates. The moisture was determined by oven drying at $110 \pm 5$ C according to the standard (EN 1097-6, 2014) until a weight difference of less than $0.1 \%$ was obtained. The average moisture of the aggregates in the concrete was $2.1 \pm$ $0.1 \%$. The value obtained from the moisture allowed the calculation of the total water-cement ratio. The average values of the total $\mathrm{w} / \mathrm{c}$ ratio of the dosages are given in Table 3 along with the standard deviation.

The mixing procedure was performed using the same amount of time and order of mixing of the components. In all cases a previous mixing of the aggregates and cement without water was carried out in a planetary concrete mixer. The water was then added together with a plasticizer/retarding admixture (TIMM-CX 69 lignosulfonate) with a percentage of $1.8 \%$ of the total cement weight. Other superplasticizer chemical admixture (Techmocem 120) was added at $1.5 \%$ of the total cement weight, approximately 1 minute before the discharge of the concrete. The rate and procedure of the addition of the admixtures were carried out as in the production of the commercial concrete used for manufacturing of the concrete caissons. Figure 3 shows images of concrete specimens along with compression and slump tests during this research. 


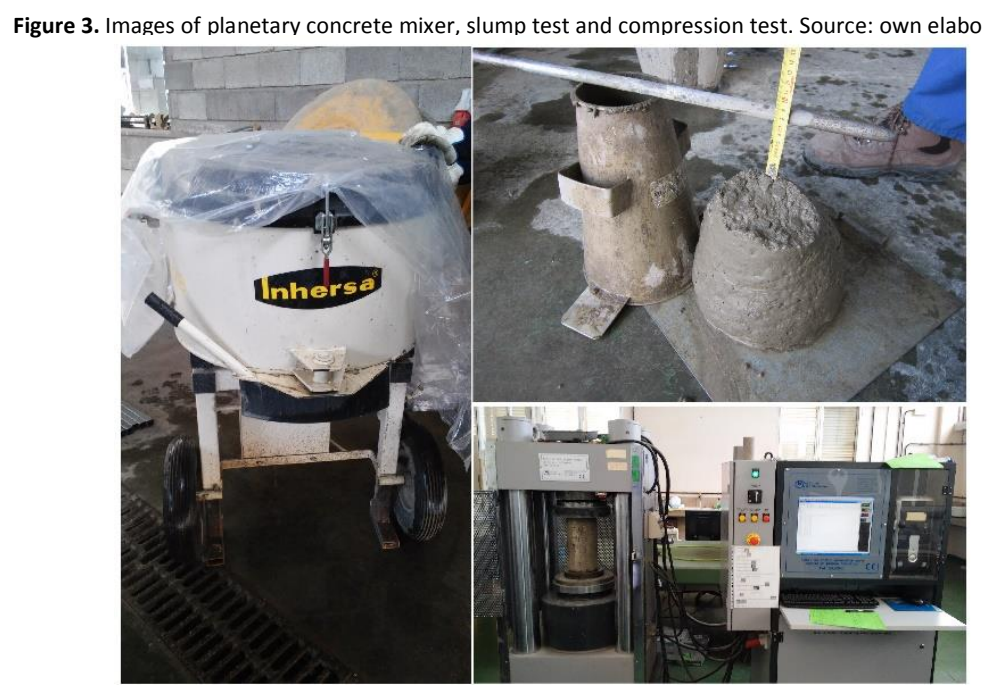

Results and discussion

\section{Density of the concretes}

The density of the fresh concrete was determined by weighing the concrete mass in a mold of $100 \mathrm{~mm} \times 100 \mathrm{~mm} \times 100$ $\mathrm{mm}$. The average values and standard error values obtained were $2457 \pm 26 \mathrm{~kg} / \mathrm{m}^{3}$ for the AF06 mix, and $2496 \pm 25 \mathrm{~kg} / \mathrm{m}^{3}$ for the AB06 mix. Once these specimen concretes were cured in a humid chamber for 28 days, each of the obtained cubic specimens were dried at $50^{\circ} \mathrm{C}$ until constant mass to avoid a change in the microstructure of the cement paste. Several researchers (Wong \& Buenfeld, 2009) suggest that the dehydration of hydration products (crystalline phases and non-crystalline phases, $\mathrm{C}-\mathrm{S}-\mathrm{H}$ gel) may have occurred at temperatures even below $105^{\circ} \mathrm{C}$. The obtained values of dry mean density for AF06 and ABO6 were $2339 \pm 30 \mathrm{~kg} / \mathrm{m}^{3}$ and $2343 \pm 48 \mathrm{~kg} / \mathrm{m}^{3}$, respectively. The results indicate that the densities of both mixes were very similar.

\section{Effect of water available in the fresh concrete}

The absorption of water by aggregates is a complex phenomenon (Domagała, 2015) and it is difficult to estimate the water actually absorbed by the aggregates. The Code on Structural Concrete (EHE-08, 2008) establishes that it is very difficult to determine the effective water-cement ratio for light aggregates due to their high water absorption. However, there are studies that attempt to calculate this effective water-cement ratio for different aggregate types using different methodologies. The study reported by (Alhozaimy, 2009) for limestone aggregates determines that the water absorption value of these aggregates in the fresh concrete is approximately $75 \%$ of their total water absorption (between 1.3-1.9\%). The basaltic aggregates included in this research are not lightweight aggregates, but their absorption is higher than $3 \%$ (Table 2). This value of water absorption for the basaltic sand is higher than African sand.

Due to the water absorption by aggregates, the water available for the hydration of the cement is less than the total added to the mixture. The relationship between the amount of water available in the fresh concrete and the weight of the cement is called: effective water-cement ratio (UNE-EN 206-1, 2008). The effective water-cement ratio can be calculated according to the Equation 1, which considers the water absorption by the aggregates included in the concrete mix.

$$
\left(\frac{w}{c}\right)_{e f f}^{p}=\frac{w_{t}-\left[\left(\frac{p}{100}\right) \cdot\left(\sum_{i=1}^{3} a_{i} \cdot m_{i}\right)\right]}{c}
$$

where $w_{t}$ is the weight of total water added to the concrete; $p$ is the percentage of water absorption by the aggregates in the fresh concrete with respect to their total water absorption; $a_{i}$ is the total water absorption of the aggregate $i$; and $m_{i}$ is the mass of the aggregate $i$. Thus, for example, for $p=100 \%$ the aggregates absorb $100 \%$ with respect to their total water absorption, and for $\mathrm{p}=0 \%$ the aggregates do not absorb water during the mixing procedure of the concrete. The $i$ subscript refers to the African sand $(i=1=\mathrm{AO} / 2)$, basaltic sand $(i=2=\mathrm{A} 0 / 6)$, and basaltic coarse aggregate $(i=3=\mathrm{G} 10 / 20)$. 
In each mixture, the fresh concrete was extracted in order to quantify its slump (EN 12350-2, 2009). The slump of the fresh concrete depends on the amount of water available in the mixture. The total water-cement ratio does not represent the water available in the fresh concrete because it does not consider the water absorption by the aggregates; nevertheless, the effective water-cement ratio does consider it. When the effective water-cement ratio is considered, the slump would be independent of the aggregate type included in the concrete. Therefore, the best correlation between the slumps and $(w / c)_{\text {eff }}^{p}$ for both AF06 and AB06 mixes (simultaneously) allows the estimation the water absorption value of the aggregates in the fresh concrete.

The effective water-cement ratios of the AF06 and AB06 mixes were calculated following the equation (1) for different values of $p \%$. Subsequently, the slump values were correlated for different effective water-cement ratios. As an example, Figure 4 shows the result of the linear correlation for the effective water-cement ratio calculated for both $p=0 \%$ (Figure $4 \mathrm{~A}$ ) and $p=100 \%$ (Figure $4 \mathrm{~B}$ ). The best linear regression was obtained for an effective water-cement ratio with $p=25 \%$ and $p=30 \%$ (Figure 5). Therefore, the water absorption value of the aggregates in the AF06 and AB06 mixes was estimated between $25 \%$ and $30 \%$ of their total water absorption.

Figure 4. Representation of the slump versus the effective water-cement ratio calculated for both $0 \%(\mathrm{~A})$ and $100 \%$ (B) of the total absorption capacity of the aggregates. Source: own elaboration.
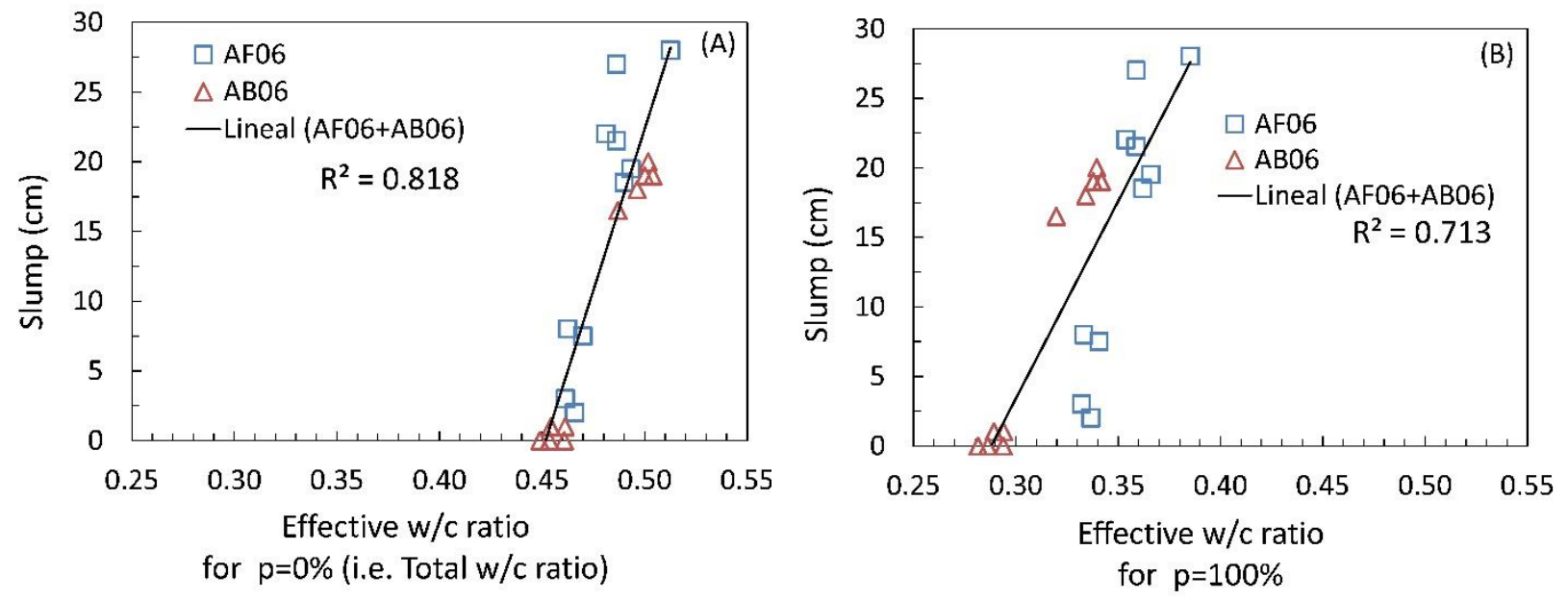

This estimated absorption is lower than that obtained by (Alhozaimy, 2009) for limestone aggregates. This may be because the mixing procedure performed for this research was the dry pre-mixing of the aggregate with the cement. This dry pre-mixing could restrain the effective absorption of the aggregates compared with an initial mixing procedure of the aggregates with water, and later the addition of the cement.

The average slump obtained for these AF06 and AB06 mixes were $16 \mathrm{~cm}$ and $9 \mathrm{~cm}$, respectively. The slump values have a great dispersion due to the sensitivity of the slump test with small variations of the w/c ratio (between $0.43-0.51$, see Figure 4 for $p=0 \%$ ). The slump values were always less than $8 \mathrm{~cm}$ for total $w / c$ ratios less than 0.47 . The AF06 mix obtained a slump values higher than AB06 mix for a same w/c ratio. The slump is different for the AF06 and AB06 mixes precisely because these mixtures of concrete have different amounts of available water in the fresh concrete.

Figure 5. $\mathrm{R}^{2}$ linear versus the percentage of water absorption of the aggregates in the fresh concrete $(A)$, and representation of the two best linear regression of the slump versus the effective water-cement ratio (B). Source: own elaboration. 


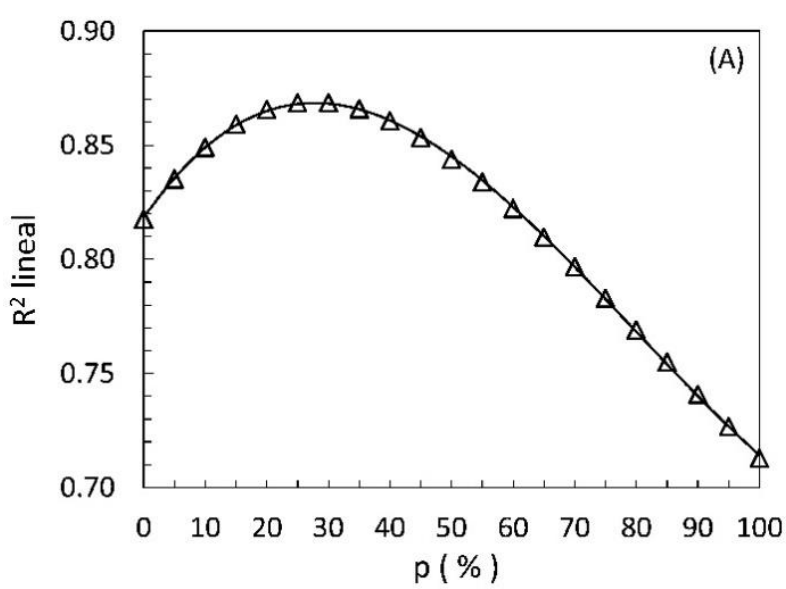

Effect of the presence of the African sand in the strength of the concrete

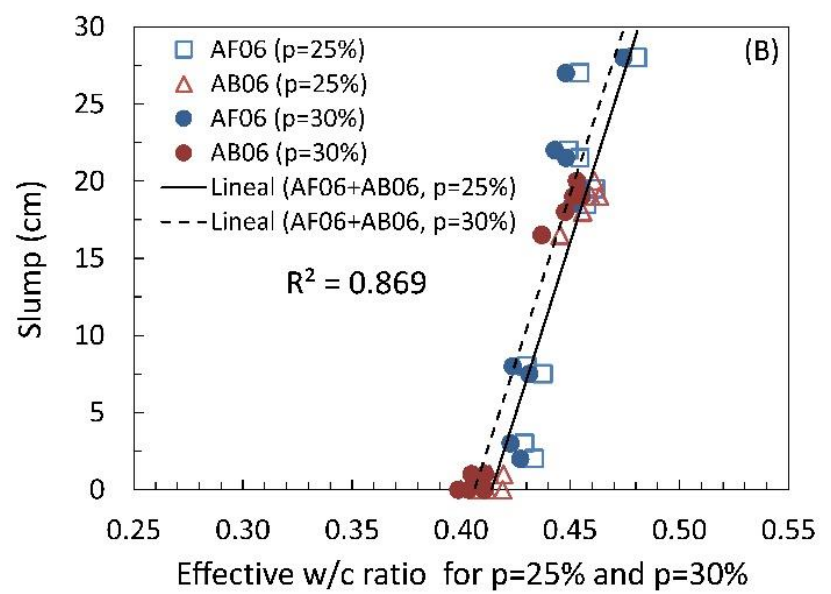

The AF06 and AB06 mixes differ in the substitution of a specific amount of the basaltic sand for African sand. Cylindrical specimens of $150 \mathrm{~mm} \times 300 \mathrm{~mm}$ were made for the determination of the compression strength (EN 12390-3, 2009) after 28 days of curing in a humid chamber. A total of 80 specimens were performed and tested, 40 of the AF06 mixes and 40 of the AB06 mixes. The average compression strength and standard deviation obtained was $63 \pm 11 \mathrm{MPa}$ for AF06 mix and $67 \pm 6 \mathrm{MPa}$ for $\mathrm{AB} 06$ mix. The range of the resistance data of the AF06 mix is greater than the range of data of the compression strength for the AB06 mix (Figure 6).

The Mann-Whitney $U$ test is a non-parametric test that was used to test the null hypothesis. This nonparametric test is adequate for the case in which the assumption of normality is not satisfied and the samples are relatively small. The application of the Mann-Whitney $U$ test (IBM Corp., 2010) shows that it is not possible to conclude that there is a difference in the compression strength values of the AF06 and AB06 mixes, with a p-value=0.467.

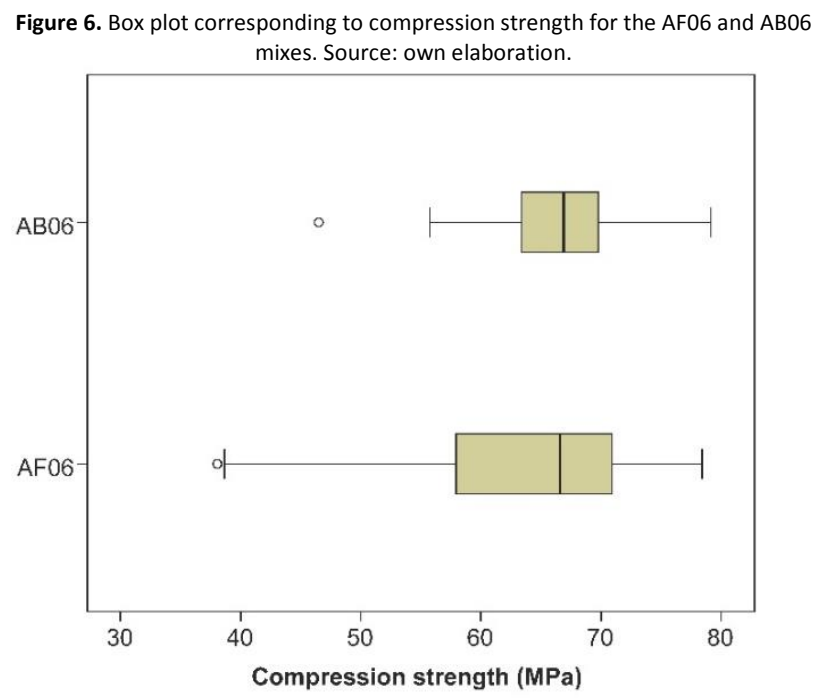

This work present a methodology proposal for the determination of the effective water-cement ratio using aggregates with different water absorption. The water absorption value of the basaltic aggregates was estimated to be between $25 \%$ and $30 \%$ of their total absorption capacity with a previous mixing procedure performed by dry pre-mixing of the aggregate with the cement. This procedure avoids an absorption of more water by the aggregate because the water is not added directly together with the aggregate. 
The high absorption of water of the basaltic aggregates causes a loss of available water on the fresh concrete that leads to less slump values. The results show that the average slump obtained for the concrete containing African sand was higher than the average slump in the concretes made only with basaltic aggregates. For the same total water-cement ratio, the incorporation of the African sand in the concrete causes an improvement in the concrete workability because the concrete has more water that is available.

The results indicate that it is not possible to conclude that there is a difference in the compression strength values between the AF06 and AB06 mixes. In other words, the substitution of $17 \%$ of basaltic sand by African sand does not improve the compression strength of the concrete mix studied, which was employed for the manufacture of concrete caissons used in a maritime works. The slight difference between the average strength of AF06 and AB06 mixes may be due to the fact that the high porosity of the fine aggregate of basalt causes a lower effective water-cement ratio for the mixture AB06, and therefore a higher average strength.

\section{Acknowledgements}

The authors thank the Consejería de Obras Públicas, Transportes y Política Territorial of the Canarian Government (Spain) for the human and technical resources provided, as well as the General Service Research Support (http://www.segai.ull.es/) of the Universidad de La Laguna (Islas Canarias, Spain) for the scientific, instrumental and technical support. The authors also wish to express their appreciation to Eng. Juan Antonio Afonso Mosegue for providing assistance with the basaltic aggregates, as well as to Techmo Company (Spain) for supplying the admixtures.

References

Alhozaimy, A. M. (2009). Effect of absorption of limestone aggregates on strength and slump loss of concrete. Cement and Concrete Composites, 31(7), 470-473. http://doi.org/10.1016/j.cemconcomp.2009.04.010

Castro, J., Keiser, L., Golias, M., \& Weiss, J. (2011). Absorption and desorption properties of fine lightweight aggregate for application to internally cured concrete mixtures. Cement and Concrete Composites, 33(10), 1001-1008. http://doi.org/10.1016/j.cemconcomp.2011.07.006

Domagała, L. (2015). The effect of lightweight aggregate water absorption on the reduction of water-cement ratio in fresh concrete. In Procedia Engineering (Vol. 108, pp. 206-213). http://doi.org/10.1016/j.proeng.2015.06.139

EHE-08. (2008). Spanish Code on Structural Concrete. Ministerio de Fomento. Gobierno de España.

EN 1097-6. (2014). European Standard. Tests for mechanical and physical properties of aggregates. Part 6: Determination of particle density and water absorption.

EN 12350-2. (2009). European Standard. Testing fresh concrete. Part 2: Slump test.

EN 12390-3. (2009). European Standard. Testing hardened concrete. Part 3: Compressive strength of test specimens.

EN 933-1. (2012). European Standard. Test for geometrical properties of aggregates. Part 1: Determination of particle size distribution. Sieving method.

Golias, M., Castro, J., \& Weiss, J. (2012). The influence of the initial moisture content of lightweight aggregate on internal curing. Construction and Building Materials, 35, 52-62. http://doi.org/10.1016/j.conbuildmat.2012.02.074

Henkensiefken, R., Castro, J., Bentz, D., Nantung, T., \& Weiss, J. (2009). Water absorption in internally cured mortar made with water-filled lightweight aggregate. Cement and Concrete Research. http://doi.org/10.1016/j.cemconres.2009.06.009

IBM Corp. (2010). SPSS Statistics. Armonk, NY: IBM Company.

Karpuz, O., Vefa Akpinar, M., \& Mutlu Aydin, M. (2017). Effects of fine aggregate abrasion resistance and its fineness module on wear resistance of Portland cement concrete pavements. Revista de La Construcción, 16(1), 126-132. http://doi.org/10.7764/RDLC.16.1.126

UNE-EN 206-1. (2008). European Standard. Concrete Part 1. Specification, performance, production and conformity.

UNE 80303-2. (2011). Spanish Standards. Cements with additional characteristics. Part 2: Sea water resisting cements.

Wong, H. S., \& Buenfeld, N. R. (2009). Determining the water-cement ratio, cement content, water content and degree of hydration of hardened cement paste: Method development and validation on paste samples. Cement and Concrete Research, 39(10), 957-965. http://doi.org/10.1016/j.cemconres.2009.06.013

Zhang, \& Gjørv. (1990). Microstructure of the interfacial zone between lightweight aggregate and cement paste. Cement and Concrete Research, 20(4), 610-618. http://doi.org/10.1016/0008-8846(90)90103-5

Zhang, \& Gjørv. (1992). Penetration of cement paste into lightweight aggregate. Cement and Concrete Research, 22(1), 47-55. http://doi.org/10.1016/0008-8846(92)90135-I

Zhang, S. P., \& Zong, L. (2014). Evaluation of Relationship between Water Absorption and Durability of Concrete Materials. http://doi.org/10.1155/2014/650373 